\title{
Convention on the Rights of the Child
}

\section{Adopted and opened for signature, ratification and accession by General Assembly resolution 44/25 of 20 November 1989}

\author{
entry into force 2 September 1990, in accordance with article 49
}

\begin{abstract}
Preamble
The States Parties to the present Convention,

Considering that, in accordance with the principles proclaimed in the Charter of the United Nations, recognition of the inherent dignity and of the equal and inalienable rights of all members of the human family is the foundation of freedom, justice and peace in the world,
\end{abstract}

Bearing in mind that the peoples of the United Nations have, in the Charter, reaffirmed their faith in fundamental human rights and in the dignity and worth of the human person, and have determined to promote social progress and better standards of life in larger freedom,

Recognizing that the United Nations has, in the Universal Declaration of Human Rights and in the International Covenants on Human Rights, proclaimed and agreed that everyone is entitled to all the rights and freedoms set forth therein, without distinction of any kind, such as race, colour, sex, language, religion, political or other opinion, national or social origin, property, birth or other status,

Recalling that, in the Universal Declaration of Human Rights, the United Nations has proclaimed that childhood is entitled to special care and assistance,

Convinced that the family, as the fundamental group of society and the natural environment for the growth and well-being of all its members and particularly children, should be afforded the necessary protection and assistance so that it can fully assume its responsibilities within the community,

Recognizing that the child, for the full and harmonious development of his or her personality, should grow up in a family environment, in an atmosphere of happiness, love and understanding,

Considering that the child should be fully prepared to live an individual life in society, and brought up in the spirit of the ideals proclaimed in the Charter of the United Nations, and in particular in the spirit of peace, dignity, tolerance, freedom, equality and solidarity,

Bearing in mind that the need to extend particular care to the child has been stated in the Geneva Declaration of the Rights of the Child of 1924 and in the Declaration of the Rights of the Child adopted by the General Assembly on 20 November 1959 and recognized in the Universal Declaration of Human Rights, in the International Covenant on Civil and Political Rights (in particular in articles 23 and 24), in the International Covenant on Economic, Social and Cultural Rights (in particular in article 10) and in the statutes and relevant instruments of specialized agencies and international organizations concerned with the welfare of children,

Bearing in mind that, as indicated in the Declaration of the Rights of the Child, "the child, by reason of his physical and mental immaturity, needs special safeguards and care, including appropriate legal protection, before as well as after birth",

Recalling the provisions of the Declaration on Social and Legal Principles relating to the Protection and Welfare of Children, with Special Reference to Foster Placement and Adoption Nationally and Internationally; the United Nations Standard Minimum Rules for the Administration of Juvenile Justice (The Beijing Rules); and the Declaration on the Protection of Women and Children in Emergency and Armed Conflict, Recognizing that, in all countries in the world, there are children living in exceptionally difficult conditions, and that such children need special consideration, 
Taking due account of the importance of the traditions and cultural values of each people for the protection and harmonious development of the child, Recognizing the importance of international cooperation for improving the living conditions of children in every country, in particular in the developing countries,

Have agreed as follows:

\section{PART I}

\section{Article 1}

For the purposes of the present Convention, a child means every human being below the age of eighteen years unless under the law applicable to the child, majority is attained earlier.

\section{Article 2}

1. States Parties shall respect and ensure the rights set forth in the present Convention to each child within their jurisdiction without discrimination of any kind, irrespective of the child's or his or her parent's or legal guardian's race, colour, sex, language, religion, political or other opinion, national, ethnic or social origin, property, disability, birth or other status.

2. States Parties shall take all appropriate measures to ensure that the child is protected against all forms of discrimination or punishment on the basis of the status, activities, expressed opinions, or beliefs of the child's parents, legal guardians, or family members.

\section{Article 3}

1. In all actions concerning children, whether undertaken by public or private social welfare institutions, courts of law, administrative authorities or legislative bodies, the best interests of the child shall be a primary consideration.

2. States Parties undertake to ensure the child such protection and care as is necessary for his or her well-being, taking into account the rights and duties of his or her parents, legal guardians, or other individuals legally responsible for him or her, and, to this end, shall take all appropriate legislative and administrative measures.

3. States Parties shall ensure that the institutions, services and facilities responsible for the care or protection of children shall conform with the standards established by competent authorities, particularly in the areas of safety, health, in the number and suitability of their staff, as well as competent supervision.

\section{Article 4}

States Parties shall undertake all appropriate legislative, administrative, and other measures for the implementation of the rights recognized in the present Convention. With regard to economic, social and cultural rights, States Parties shall undertake such measures to the maximum extent of their available resources and, where needed, within the framework of international co-operation.

\section{Article 5}

States Parties shall respect the responsibilities, rights and duties of parents or, where applicable, the members of the extended family or community as provided for by local custom, legal guardians or other persons legally responsible for the child, to provide, in a manner consistent with the evolving capacities of the child, appropriate direction and guidance in the exercise by the child of the rights recognized in the present Convention.

\section{Article 6}


1. States Parties recognize that every child has the inherent right to life. 2 . States Parties shall ensure to the maximum extent possible the survival and development of the child.

\section{Article 7}

1. The child shall be registered immediately after birth and shall have the right from birth to a name, the right to acquire a nationality and. as far as possible, the right to know and be cared for by his or her parents.

2. States Parties shall ensure the implementation of these rights in accordance with their national law and their obligations under the relevant international instruments in this field, in particular where the child would otherwise be stateless.

\section{Article 8}

1. States Parties undertake to respect the right of the child to preserve his or her identity, including nationality, name and family relations as recognized by law without unlawful interference.

2. Where a child is illegally deprived of some or all of the elements of his or her identity, States Parties shall provide appropriate assistance and protection, with a view to re-establishing speedily his or her identity.

\section{Article 9}

1. States Parties shall ensure that a child shall not be separated from his or her parents against their will, except when competent authorities subject to judicial review determine, in accordance with applicable law and procedures, that such separation is necessary for the best interests of the child. Such determination may be necessary in a particular case such as one involving abuse or neglect of the child by the parents, or one where the parents are living separately and a decision must be made as to the child's place of residence.

2. In any proceedings pursuant to paragraph 1 of the present article, all interested parties shall be given an opportunity to participate in the proceedings and make their views known.

3. States Parties shall respect the right of the child who is separated from one or both parents to maintain personal relations and direct contact with both parents on a regular basis, except if it is contrary to the child's best interests.

4. Where such separation results from any action initiated by a State Party, such as the detention, imprisonment, exile, deportation or death (including death arising from any cause while the person is in the custody of the State) of one or both parents or of the child, that State Party shall, upon request, provide the parents, the child or, if appropriate, another member of the family with the essential information concerning the whereabouts of the absent member(s) of the family unless the provision of the information would be detrimental to the well-being of the child. States Parties shall further ensure that the submission of such a request shall of itself entail no adverse consequences for the person(s) concerned.

\section{Article 10}

1. In accordance with the obligation of States Parties under article 9, paragraph 1, applications by a child or his or her parents to enter or leave a State Party for the purpose of family reunification shall be dealt with by States Parties in a positive, humane and expeditious manner. States Parties shall further ensure that the submission of such a request shall entail no adverse consequences for the applicants and for the members of their family.

2. A child whose parents reside in different States shall have the right to maintain on a regular basis, save in exceptional circumstances personal relations and direct contacts with both parents. Towards that end and in accordance with the obligation of States Parties under article 9, paragraph 1, States Parties shall respect the right of the child and his or her parents to leave any country, including their 
own, and to enter their own country. The right to leave any country shall be subject only to such restrictions as are prescribed by law and which are necessary to protect the national security, public order (ordre public), public health or morals or the rights and freedoms of others and are consistent with the other rights recognized in the present Convention.

\section{Article 11}

1. States Parties shall take measures to combat the illicit transfer and non-return of children abroad.

2. To this end, States Parties shall promote the conclusion of bilateral or multilateral agreements or accession to existing agreements.

\section{Article 12}

1. States Parties shall assure to the child who is capable of forming his or her own views the right to express those views freely in all matters affecting the child, the views of the child being given due weight in accordance with the age and maturity of the child.

2. For this purpose, the child shall in particular be provided the opportunity to be heard in any judicial and administrative proceedings affecting the child, either directly, or through a representative or an appropriate body, in a manner consistent with the procedural rules of national law.

\section{Article 13}

1. The child shall have the right to freedom of expression; this right shall include freedom to seek, receive and impart information and ideas of all kinds, regardless of frontiers, either orally, in writing or in print, in the form of art, or through any other media of the child's choice.

2. The exercise of this right may be subject to certain restrictions, but these shall only be such as are provided by law and are necessary:

(a) For respect of the rights or reputations of others; or

(b) For the protection of national security or of public order (ordre public), or of public health or morals.

\section{Article 14}

1. States Parties shall respect the right of the child to freedom of thought, conscience and religion.

2. States Parties shall respect the rights and duties of the parents and, when applicable, legal guardians, to provide direction to the child in the exercise of his or her right in a manner consistent with the evolving capacities of the child.

3. Freedom to manifest one's religion or beliefs may be subject only to such limitations as are prescribed by law and are necessary to protect public safety, order, health or morals, or the fundamental rights and freedoms of others.

\section{Article 15}

1. States Parties recognize the rights of the child to freedom of association and to freedom of peaceful assembly.

2. No restrictions may be placed on the exercise of these rights other than those imposed in conformity with the law and which are necessary in a democratic society in the interests of national security or public safety, public order (ordre public), the protection of public health or morals or the protection of the rights and freedoms of others.

\section{Article 16}


1. No child shall be subjected to arbitrary or unlawful interference with his or her privacy, family, home or correspondence, nor to unlawful attacks on his or her honour and reputation.

2. The child has the right to the protection of the law against such interference or attacks.

\section{Article 17}

States Parties recognize the important function performed by the mass media and shall ensure that the child has access to information and material from a diversity of national and international sources, especially those aimed at the promotion of his or her social, spiritual and moral well-being and physical and mental health.

To this end, States Parties shall:

(a) Encourage the mass media to disseminate information and material of social and cultural benefit to the child and in accordance with the spirit of article 29;

(b) Encourage international co-operation in the production, exchange and dissemination of such information and material from a diversity of cultural, national and international sources;

(c) Encourage the production and dissemination of children's books;

(d) Encourage the mass media to have particular regard to the linguistic needs of the child who belongs to a minority group or who is indigenous;

(e) Encourage the development of appropriate guidelines for the protection of the child from information and material injurious to his or her well-being, bearing in mind the provisions of articles 13 and 18.

\section{Article 18}

1. States Parties shall use their best efforts to ensure recognition of the principle that both parents have common responsibilities for the upbringing and development of the child. Parents or, as the case may be, legal guardians, have the primary responsibility for the upbringing and development of the child. The best interests of the child will be their basic concern.

2. For the purpose of guaranteeing and promoting the rights set forth in the present Convention, States Parties shall render appropriate assistance to parents and legal guardians in the performance of their child-rearing responsibilities and shall ensure the development of institutions, facilities and services for the care of children.

3. States Parties shall take all appropriate measures to ensure that children of working parents have the right to benefit from child-care services and facilities for which they are eligible.

\section{Article 19}

1. States Parties shall take all appropriate legislative, administrative, social and educational measures to protect the child from all forms of physical or mental violence, injury or abuse, neglect or negligent treatment, maltreatment or exploitation, including sexual abuse, while in the care of parent(s), legal guardian(s) or any other person who has the care of the child.

2. Such protective measures should, as appropriate, include effective procedures for the establishment of social programmes to provide necessary support for the child and for those who have the care of the child, as well as for other forms of prevention and for identification, reporting, referral, investigation, treatment and follow-up of instances of child maltreatment described heretofore, and, as appropriate, for judicial involvement.

\section{Article 20}


1. A child temporarily or permanently deprived of his or her family environment, or in whose own best interests cannot be allowed to remain in that environment, shall be entitled to special protection and assistance provided by the State.

2. States Parties shall in accordance with their national laws ensure alternative care for such a child.

3. Such care could include, inter alia, foster placement, kafalah of Islamic law, adoption or if necessary placement in suitable institutions for the care of children. When considering solutions, due regard shall be paid to the desirability of continuity in a child's upbringing and to the child's ethnic, religious, cultural and linguistic background.

\section{Article 21}

States Parties that recognize and/or permit the system of adoption shall ensure that the best interests of the child shall be the paramount consideration and they shall:

(a) Ensure that the adoption of a child is authorized only by competent authorities who determine, in accordance with applicable law and procedures and on the basis of all pertinent and reliable information, that the adoption is permissible in view of the child's status concerning parents, relatives and legal guardians and that, if required, the persons concerned have given their informed consent to the adoption on the basis of such counselling as may be necessary;

(b) Recognize that inter-country adoption may be considered as an alternative means of child's care, if the child cannot be placed in a foster or an adoptive family or cannot in any suitable manner be cared for in the child's country of origin;

(c) Ensure that the child concerned by inter-country adoption enjoys safeguards and standards equivalent to those existing in the case of national adoption;

(d) Take all appropriate measures to ensure that, in inter-country adoption, the placement does not result in improper financial gain for those involved in it;

(e) Promote, where appropriate, the objectives of the present article by concluding bilateral or multilateral arrangements or agreements, and endeavour, within this framework, to ensure that the placement of the child in another country is carried out by competent authorities or organs.

\section{Article 22}

1. States Parties shall take appropriate measures to ensure that a child who is seeking refugee status or who is considered a refugee in accordance with applicable international or domestic law and procedures shall, whether unaccompanied or accompanied by his or her parents or by any other person, receive appropriate protection and humanitarian assistance in the enjoyment of applicable rights set forth in the present Convention and in other international human rights or humanitarian instruments to which the said States are Parties.

2. For this purpose, States Parties shall provide, as they consider appropriate, co-operation in any efforts by the United Nations and other competent intergovernmental organizations or nongovernmental organizations co-operating with the United Nations to protect and assist such a child and to trace the parents or other members of the family of any refugee child in order to obtain information necessary for reunification with his or her family. In cases where no parents or other members of the family can be found, the child shall be accorded the same protection as any other child permanently or temporarily deprived of his or her family environment for any reason, as set forth in the present Convention.

\section{Article 23}


1. States Parties recognize that a mentally or physically disabled child should enjoy a full and decent life, in conditions which ensure dignity, promote self-reliance and facilitate the child's active participation in the community.

2. States Parties recognize the right of the disabled child to special care and shall encourage and ensure the extension, subject to available resources, to the eligible child and those responsible for his or her care, of assistance for which application is made and which is appropriate to the child's condition and to the circumstances of the parents or others caring for the child.

3. Recognizing the special needs of a disabled child, assistance extended in accordance with paragraph 2 of the present article shall be provided free of charge, whenever possible, taking into account the financial resources of the parents or others caring for the child, and shall be designed to ensure that the disabled child has effective access to and receives education, training, health care services, rehabilitation services, preparation for employment and recreation opportunities in a manner conducive to the child's achieving the fullest possible social integration and individual development, including his or her cultural and spiritual development

4. States Parties shall promote, in the spirit of international cooperation, the exchange of appropriate information in the field of preventive health care and of medical, psychological and functional treatment of disabled children, including dissemination of and access to information concerning methods of rehabilitation, education and vocational services, with the aim of enabling States Parties to improve their capabilities and skills and to widen their experience in these areas. In this regard, particular account shall be taken of the needs of developing countries.

\section{Article 24}

1. States Parties recognize the right of the child to the enjoyment of the highest attainable standard of health and to facilities for the treatment of illness and rehabilitation of health. States Parties shall strive to ensure that no child is deprived of his or her right of access to such health care services.

2. States Parties shall pursue full implementation of this right and, in particular, shall take appropriate measures:

(a) To diminish infant and child mortality;

(b) To ensure the provision of necessary medical assistance and health care to all children with emphasis on the development of primary health care;

(c) To combat disease and malnutrition, including within the framework of primary health care, through, inter alia, the application of readily available technology and through the provision of adequate nutritious foods and clean drinking-water, taking into consideration the dangers and risks of environmental pollution;

(d) To ensure appropriate pre-natal and post-natal health care for mothers;

(e) To ensure that all segments of society, in particular parents and children, are informed, have access to education and are supported in the use of basic knowledge of child health and nutrition, the advantages of breastfeeding, hygiene and environmental sanitation and the prevention of accidents;

(f) To develop preventive health care, guidance for parents and family planning education and services.

3. States Parties shall take all effective and appropriate measures with a view to abolishing traditional practices prejudicial to the health of children.

4. States Parties undertake to promote and encourage international co-operation with a view to achieving progressively the full realization of the right recognized in the present article. In this regard, particular account shall be taken of the needs of developing countries. 


\section{Article 25}

States Parties recognize the right of a child who has been placed by the competent authorities for the purposes of care, protection or treatment of his or her physical or mental health, to a periodic review of the treatment provided to the child and all other circumstances relevant to his or her placement.

\section{Article 26}

1. States Parties shall recognize for every child the right to benefit from social security, including social insurance, and shall take the necessary measures to achieve the full realization of this right in accordance with their national law.

2. The benefits should, where appropriate, be granted, taking into account the resources and the circumstances of the child and persons having responsibility for the maintenance of the child, as well as any other consideration relevant to an application for benefits made by or on behalf of the child.

\section{Article 27}

1. States Parties recognize the right of every child to a standard of living adequate for the child's physical, mental, spiritual, moral and social development.

2. The parent(s) or others responsible for the child have the primary responsibility to secure, within their abilities and financial capacities, the conditions of living necessary for the child's development.

3. States Parties, in accordance with national conditions and within their means, shall take appropriate measures to assist parents and others responsible for the child to implement this right and shall in case of need provide material assistance and support programmes, particularly with regard to nutrition, clothing and housing.

4. States Parties shall take all appropriate measures to secure the recovery of maintenance for the child from the parents or other persons having financial responsibility for the child, both within the State Party and from abroad. In particular, where the person having financial responsibility for the child lives in a State different from that of the child, States Parties shall promote the accession to international agreements or the conclusion of such agreements, as well as the making of other appropriate arrangements.

\section{Article 28}

1. States Parties recognize the right of the child to education, and with a view to achieving this right progressively and on the basis of equal opportunity, they shall, in particular:

(a) Make primary education compulsory and available free to all;

(b) Encourage the development of different forms of secondary education, including general and vocational education, make them available and accessible to every child, and take appropriate measures such as the introduction of free education and offering financial assistance in case of need;

(c) Make higher education accessible to all on the basis of capacity by every appropriate means;

(d) Make educational and vocational information and guidance available and accessible to all children;

(e) Take measures to encourage regular attendance at schools and the reduction of drop-out rates.

2. States Parties shall take all appropriate measures to ensure that school discipline is administered in a manner consistent with the child's human dignity and in conformity with the present Convention.

3. States Parties shall promote and encourage international cooperation in matters relating to education, in particular with a view to contributing to the elimination of ignorance and illiteracy 
throughout the world and facilitating access to scientific and technical knowledge and modern teaching methods. In this regard, particular account shall be taken of the needs of developing countries.

\section{Article 29}

1. States Parties agree that the education of the child shall be directed to:

(a) The development of the child's personality, talents and mental and physical abilities to their fullest potential;

(b) The development of respect for human rights and fundamental freedoms, and for the principles enshrined in the Charter of the United Nations;

(c) The development of respect for the child's parents, his or her own cultural identity, language and values, for the national values of the country in which the child is living, the country from which he or she may originate, and for civilizations different from his or her own;

(d) The preparation of the child for responsible life in a free society, in the spirit of understanding, peace, tolerance, equality of sexes, and friendship among all peoples, ethnic, national and religious groups and persons of indigenous origin;

(e) The development of respect for the natural environment.

2. No part of the present article or article 28 shall be construed so as to interfere with the liberty of individuals and bodies to establish and direct educational institutions, subject always to the observance of the principle set forth in paragraph 1 of the present article and to the requirements that the education given in such institutions shall conform to such minimum standards as may be laid down by the State.

\section{Article 30}

In those States in which ethnic, religious or linguistic minorities or persons of indigenous origin exist, a child belonging to such a minority or who is indigenous shall not be denied the right, in community with other members of his or her group, to enjoy his or her own culture, to profess and practise his or her own religion, or to use his or her own language.

\section{Article 31}

1. States Parties recognize the right of the child to rest and leisure, to engage in play and recreational activities appropriate to the age of the child and to participate freely in cultural life and the arts.

2. States Parties shall respect and promote the right of the child to participate fully in cultural and artistic life and shall encourage the provision of appropriate and equal opportunities for cultural, artistic, recreational and leisure activity.

\section{Article 32}

1. States Parties recognize the right of the child to be protected from economic exploitation and from performing any work that is likely to be hazardous or to interfere with the child's education, or to be harmful to the child's health or physical, mental, spiritual, moral or social development.

2. States Parties shall take legislative, administrative, social and educational measures to ensure the implementation of the present article. To this end, and having regard to the relevant provisions of other international instruments, States Parties shall in particular:

(a) Provide for a minimum age or minimum ages for admission to employment;

(b) Provide for appropriate regulation of the hours and conditions of employment; 
(c) Provide for appropriate penalties or other sanctions to ensure the effective enforcement of the present article.

\section{Article 33}

States Parties shall take all appropriate measures, including legislative, administrative, social and educational measures, to protect children from the illicit use of narcotic drugs and psychotropic substances as defined in the relevant international treaties, and to prevent the use of children in the illicit production and trafficking of such substances.

\section{Article 34}

States Parties undertake to protect the child from all forms of sexual exploitation and sexual abuse. For these purposes, States Parties shall in particular take all appropriate national, bilateral and multilateral measures to prevent:

(a) The inducement or coercion of a child to engage in any unlawful sexual activity;

(b) The exploitative use of children in prostitution or other unlawful sexual practices;

(c) The exploitative use of children in pornographic performances and materials.

\section{Article 35}

States Parties shall take all appropriate national, bilateral and multilateral measures to prevent the abduction of, the sale of or traffic in children for any purpose or in any form.

\section{Article 36}

States Parties shall protect the child against all other forms of exploitation prejudicial to any aspects of the child's welfare.

\section{Article 37}

States Parties shall ensure that:

(a) No child shall be subjected to torture or other cruel, inhuman or degrading treatment or punishment. Neither capital punishment nor life imprisonment without possibility of release shall be imposed for offences committed by persons below eighteen years of age;

(b) No child shall be deprived of his or her liberty unlawfully or arbitrarily. The arrest, detention or imprisonment of a child shall be in conformity with the law and shall be used only as a measure of last resort and for the shortest appropriate period of time;

(c) Every child deprived of liberty shall be treated with humanity and respect for the inherent dignity of the human person, and in a manner which takes into account the needs of persons of his or her age. In particular, every child deprived of liberty shall be separated from adults unless it is considered in the child's best interest not to do so and shall have the right to maintain contact with his or her family through correspondence and visits, save in exceptional circumstances;

(d) Every child deprived of his or her liberty shall have the right to prompt access to legal and other appropriate assistance, as well as the right to challenge the legality of the deprivation of his or her liberty before a court or other competent, independent and impartial authority, and to a prompt decision on any such action.

\section{Article 38}

1. States Parties undertake to respect and to ensure respect for rules of international humanitarian law applicable to them in armed conflicts which are relevant to the child. 
2. States Parties shall take all feasible measures to ensure that persons who have not attained the age of fifteen years do not take a direct part in hostilities.

3. States Parties shall refrain from recruiting any person who has not attained the age of fifteen years into their armed forces. In recruiting among those persons who have attained the age of fifteen years but who have not attained the age of eighteen years, States Parties shall endeavour to give priority to those who are oldest.

4. In accordance with their obligations under international humanitarian law to protect the civilian population in armed conflicts, States Parties shall take all feasible measures to ensure protection and care of children who are affected by an armed conflict.

\section{Article 39}

States Parties shall take all appropriate measures to promote physical and psychological recovery and social reintegration of a child victim of: any form of neglect, exploitation, or abuse; torture or any other form of cruel, inhuman or degrading treatment or punishment; or armed conflicts. Such recovery and reintegration shall take place in an environment which fosters the health, self-respect and dignity of the child.

\section{Article 40}

1. States Parties recognize the right of every child alleged as, accused of, or recognized as having infringed the penal law to be treated in a manner consistent with the promotion of the child's sense of dignity and worth, which reinforces the child's respect for the human rights and fundamental freedoms of others and which takes into account the child's age and the desirability of promoting the child's reintegration and the child's assuming a constructive role in society.

2. To this end, and having regard to the relevant provisions of international instruments, States Parties shall, in particular, ensure that:

(a) No child shall be alleged as, be accused of, or recognized as having infringed the penal law by reason of acts or omissions that were not prohibited by national or international law at the time they were committed;

(b) Every child alleged as or accused of having infringed the penal law has at least the following guarantees:

(i) To be presumed innocent until proven guilty according to law;

(ii) To be informed promptly and directly of the charges against him or her, and, if appropriate, through his or her parents or legal guardians, and to have legal or other appropriate assistance in the preparation and presentation of his or her defence;

(iii) To have the matter determined without delay by a competent, independent and impartial authority or judicial body in a fair hearing according to law, in the presence of legal or other appropriate assistance and, unless it is considered not to be in the best interest of the child, in particular, taking into account his or her age or situation, his or her parents or legal guardians;

(iv) Not to be compelled to give testimony or to confess guilt; to examine or have examined adverse witnesses and to obtain the participation and examination of witnesses on his or her behalf under conditions of equality;

(v) If considered to have infringed the penal law, to have this decision and any measures imposed in consequence thereof reviewed by a higher competent, independent and impartial authority or judicial body according to law; 
(vi) To have the free assistance of an interpreter if the child cannot understand or speak the language used;

(vii) To have his or her privacy fully respected at all stages of the proceedings.

3. States Parties shall seek to promote the establishment of laws, procedures, authorities and institutions specifically applicable to children alleged as, accused of, or recognized as having infringed the penal law, and, in particular:

(a) The establishment of a minimum age below which children shall be presumed not to have the capacity to infringe the penal law;

(b) Whenever appropriate and desirable, measures for dealing with such children without resorting to judicial proceedings, providing that human rights and legal safeguards are fully respected. 4. A variety of dispositions, such as care, guidance and supervision orders; counselling; probation; foster care; education and vocational training programmes and other alternatives to institutional care shall be available to ensure that children are dealt with in a manner appropriate to their well-being and proportionate both to their circumstances and the offence.

\section{Article 41}

Nothing in the present Convention shall affect any provisions which are more conducive to the realization of the rights of the child and which may be contained in:

(a) The law of a State party; or

(b) International law in force for that State.

\section{PART II}

\section{Article 42}

States Parties undertake to make the principles and provisions of the Convention widely known, by appropriate and active means, to adults and children alike.

\section{Article 43}

1. For the purpose of examining the progress made by States Parties in achieving the realization of the obligations undertaken in the present Convention, there shall be established a Committee on the Rights of the Child, which shall carry out the functions hereinafter provided.

2. The Committee shall consist of ten experts of high moral standing and recognized competence in the field covered by this Convention. The members of the Committee shall be elected by States Parties from among their nationals and shall serve in their personal capacity, consideration being given to equitable geographical distribution, as well as to the principal legal systems.

3. The members of the Committee shall be elected by secret ballot from a list of persons nominated by States Parties. Each State Party may nominate one person from among its own nationals.

4. The initial election to the Committee shall be held no later than six months after the date of the entry into force of the present Convention and thereafter every second year. At least four months before the date of each election, the Secretary-General of the United Nations shall address a letter to States Parties inviting them to submit their nominations within two months. The Secretary-General shall subsequently prepare a list in alphabetical order of all persons thus nominated, indicating States Parties which have nominated them, and shall submit it to the States Parties to the present Convention.

5. The elections shall be held at meetings of States Parties convened by the Secretary-General at United Nations Headquarters. At those meetings, for which two thirds of States Parties shall constitute 
a quorum, the persons elected to the Committee shall be those who obtain the largest number of votes and an absolute majority of the votes of the representatives of States Parties present and voting.

6. The members of the Committee shall be elected for a term of four years. They shall be eligible for re-election if renominated. The term of five of the members elected at the first election shall expire at the end of two years; immediately after the first election, the names of these five members shall be chosen by lot by the Chairman of the meeting.

7. If a member of the Committee dies or resigns or declares that for any other cause he or she can no longer perform the duties of the Committee, the State Party which nominated the member shall appoint another expert from among its nationals to serve for the remainder of the term, subject to the approval of the Committee.

8. The Committee shall establish its own rules of procedure.

9. The Committee shall elect its officers for a period of two years.

10. The meetings of the Committee shall normally be held at United Nations Headquarters or at any other convenient place as determined by the Committee. The Committee shall normally meet annually. The duration of the meetings of the Committee shall be determined, and reviewed, if necessary, by a meeting of the States Parties to the present Convention, subject to the approval of the General Assembly.

11. The Secretary-General of the United Nations shall provide the necessary staff and facilities for the effective performance of the functions of the Committee under the present Convention.

12. With the approval of the General Assembly, the members of the Committee established under the present Convention shall receive emoluments from United Nations resources on such terms and conditions as the Assembly may decide.

\section{Article 44}

1. States Parties undertake to submit to the Committee, through the Secretary-General of the United Nations, reports on the measures they have adopted which give effect to the rights recognized herein and on the progress made on the enjoyment of those rights

(a) Within two years of the entry into force of the Convention for the State Party concerned;

(b) Thereafter every five years.

2. Reports made under the present article shall indicate factors and difficulties, if any, affecting the degree of fulfilment of the obligations under the present Convention. Reports shall also contain sufficient information to provide the Committee with a comprehensive understanding of the implementation of the Convention in the country concerned.

3. A State Party which has submitted a comprehensive initial report to the Committee need not, in its subsequent reports submitted in accordance with paragraph 1 (b) of the present article, repeat basic information previously provided.

4. The Committee may request from States Parties further information relevant to the implementation of the Convention.

5. The Committee shall submit to the General Assembly, through the Economic and Social Council, every two years, reports on its activities.

6. States Parties shall make their reports widely available to the public in their own countries.

\section{Article 45}


In order to foster the effective implementation of the Convention and to encourage international cooperation in the field covered by the Convention:

(a) The specialized agencies, the United Nations Children's Fund, and other United Nations organs shall be entitled to be represented at the consideration of the implementation of such provisions of the present Convention as fall within the scope of their mandate. The Committee may invite the specialized agencies, the United Nations Children's Fund and other competent bodies as it may consider appropriate to provide expert advice on the implementation of the Convention in areas falling within the scope of their respective mandates. The Committee may invite the specialized agencies, the United Nations Children's Fund, and other United Nations organs to submit reports on the implementation of the Convention in areas falling within the scope of their activities;

(b) The Committee shall transmit, as it may consider appropriate, to the specialized agencies, the United Nations Children's Fund and other competent bodies, any reports from States Parties that contain a request, or indicate a need, for technical advice or assistance, along with the Committee's observations and suggestions, if any, on these requests or indications;

(c) The Committee may recommend to the General Assembly to request the Secretary-General to undertake on its behalf studies on specific issues relating to the rights of the child;

(d) The Committee may make suggestions and general recommendations based on information received pursuant to articles 44 and 45 of the present Convention. Such suggestions and general recommendations shall be transmitted to any State Party concerned and reported to the General Assembly, together with comments, if any, from States Parties.

\section{PART III}

\section{Article 46}

The present Convention shall be open for signature by all States.

\section{Article 47}

The present Convention is subject to ratification. Instruments of ratification shall be deposited with the Secretary-General of the United Nations.

\section{Article 48}

The present Convention shall remain open for accession by any State. The instruments of accession shall be deposited with the Secretary-General of the United Nations.

\section{Article 49}

1. The present Convention shall enter into force on the thirtieth day following the date of deposit with the Secretary-General of the United Nations of the twentieth instrument of ratification or accession.

2. For each State ratifying or acceding to the Convention after the deposit of the twentieth instrument of ratification or accession, the Convention shall enter into force on the thirtieth day after the deposit by such State of its instrument of ratification or accession.

\section{Article 50}

1. Any State Party may propose an amendment and file it with the Secretary-General of the United Nations. The Secretary-General shall thereupon communicate the proposed amendment to States Parties, with a request that they indicate whether they favour a conference of States Parties for the purpose of considering and voting upon the proposals. In the event that, within four months from the date of such communication, at least one third of the States Parties favour such a conference, the Secretary-General shall convene the conference under the auspices of the United Nations. Any 
amendment adopted by a majority of States Parties present and voting at the conference shall be submitted to the General Assembly for approval.

2. An amendment adopted in accordance with paragraph 1 of the present article shall enter into force when it has been approved by the General Assembly of the United Nations and accepted by a twothirds majority of States Parties.

3. When an amendment enters into force, it shall be binding on those States Parties which have accepted it, other States Parties still being bound by the provisions of the present Convention and any earlier amendments which they have accepted.

\section{Article 51}

1. The Secretary-General of the United Nations shall receive and circulate to all States the text of reservations made by States at the time of ratification or accession.

2. A reservation incompatible with the object and purpose of the present Convention shall not be permitted.

3. Reservations may be withdrawn at any time by notification to that effect addressed to the Secretary-General of the United Nations, who shall then inform all States. Such notification shall take effect on the date on which it is received by the Secretary-General

\section{Article 52}

A State Party may denounce the present Convention by written notification to the Secretary-General of the United Nations. Denunciation becomes effective one year after the date of receipt of the notification by the Secretary-General.

\section{Article 53}

The Secretary-General of the United Nations is designated as the depositary of the present Convention.

\section{Article 54}

The original of the present Convention, of which the Arabic, Chinese, English, French, Russian and Spanish texts are equally authentic, shall be deposited with the Secretary-General of the United Nations. IN WITNESS THEREOF the undersigned plenipotentiaries, being duly authorized thereto by their respective governments, have signed the present Convention. 